\title{
Piperine content variation in different Piper longum germplasms of North East India determined through RP-HPLC method
}

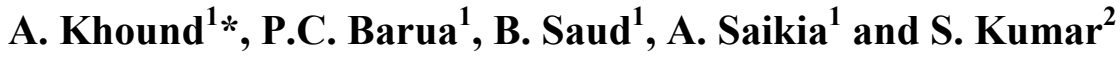 \\ ${ }^{1}$ Department of Horticulture, AAU, Jorhat (Assam), INDIA \\ ${ }^{2}$ Division of Organic chemistry, DMAP (ICAR), Anand (Gujarat), INDIA \\ *Corresponding author. E-mail: amritasharmah@gmail.com \\ Received: July 23, 2016; Revised received: January 18, 2017; Accepted: May 3, 2017
}

\begin{abstract}
The present experiment was conducted at Assam Agricultural University, Jorhat with ten accessions including check variety of Piper Longum germplasm collected from different states of North Eastern region during 2013-14 and 2014-15. The piperine, a major alkaloid used in different therapeutic treatment, per cent content was determined from dried plant materials. Deionised water was used throughout the experiment and the chromatographic separation was carried out in an isocratic elution mode on RP-18 column with $5 \mu \mathrm{m}$ particle size, $4.6 \mathrm{~mm}$ internal diameter and $250 \mathrm{~mm}$ length. The mobile phase was a mixture of methanol and water (80: 20). The solvent flow rate was $1.0 \mathrm{ml} / \mathrm{minwith}$ injection volume $20 \mu \mathrm{L}$. The photo diode array detector wavelength was set at $342 \mathrm{~nm}$ for the identification of piperine in all extracts. The per cent piperine content in extract was found to be 42.36 per cent in germplasm PLJ-30. The highest per cent piperine content in fruit was recorded in PLJ-11(7.85\%) followed by germplasm PLJ-9 (7.64) and significantly superior over check variety"Viswam"(5.15\%). The descending order of piperine content in fruits among germplasm was PLJ-11>PLJ-09>PLJ-30>PLJ-17> PLJ-03> PLJ-19> check variety>PLJ-01> PLJ-20 and PLJ-16. It can be revealed from the present experiment that piper germplasm with high piperine content has a great scope for commercial cultivation as alkaloid piperine has high demand in pharmaceutical use.
\end{abstract}

Keywords: Northeast India, Phytochemical, Piper longum, Piperine, RP-HPLC method

\section{INTRODUCTION}

Medicinal plants are used in different countries and are a source of many and varied chemical compounds leading to synthesized of many potent and powerful drugs. A total of 12,000 such compounds have been isolated so far (Tapsell et al., 2006). Piper longum L. (Piperaceae) commonly known as long pepper or pippali is native of the Indo-Malaya region. It occurs in the hotter and humid parts of India, from Central Himalayas to Assam, Khasi and the Mikir hill, the lower hills of West Bengal, and the evergreen forests of the Western Ghats from Konkan to Travancore and has also been recorded in the Car Nicobar Islands (Manoj et al., 2004). Long pepper is a slender, aromatic, perennial climber, with large woody roots and numerous creeping, jointed stems with thickened node bearing cordate leaves (Mishra, 2010). The male and female spikes are produced on different plants. The inflorescence is a cylindrical, pedunculate and flowers grow on solitary spike. The female spike is up to $2.5 \mathrm{~cm}$ long and $4-5 \mathrm{~mm}$ in diameter but the male spikes is larger, slender and narrow. The fruits are small, ovoid berries, shiny blackish green, embedded in fleshy spikes (Zaveri et al., 2010).

Indian pippali plays an important role in the increased thyroid hormone level and has a thermogenic response, i.e. the release of metabolic heat energy. Several biological activities like immunostimulatory, anti-ulcer (Sharma et al., 2012), anti-amoebic, anti-oxidant, hepatoprotective, cardiovascular and anti-inflammatory activities (Chauhan et al., 2011) were reported from the fruit of this plant. Active biomolecules from $P$. longum proved to be a source to develop MDR (multiple drugs resistant) reversal agents of natural origin to contain the development and spread of plasmid borne multiple antibiotic resistances (Kumar et al., 2013).Effect of Piper longum includes analgesic and diuretic effects, relaxation of muscles tension and alleviation of anxiety (Sunila and Kuttan, 2004). The anti-inflammatory activity of two varieties of Pippaliin acute and sub-acute experimental models of inflammation had been studied in albino rats. It was found that Chhoti variety of Pippali suppressed inflammation of both acute and sub acute phase, while Badi variety of Pippali only of acute phase (Kumariet al., 2013). Piperine is extensively used for enhancing the bioavailability and bioefficacy of various drugs (Atal and Bedi, 2010). The piperineand its analogues are potential pesticides and possess a number of medicinal properties (Okwute and Egharevba, 2013). The people of North East have a rich source of traditional knowledge system and are 
known to use herbal medicines for treatment of diseases such as cold, cough like respiratory problem, antidiabetic, headache, fever, pneumonia, skin diseases, stomach ache and many others (Choudhury et al., 2012).

The medicinal properties of $P$. longum is mainly due to the presence of secondary metabolites in fruit that contains a large number of alkaloids and related compounds, the most abundant of which is piperine, together with methyl piperine, piperonaline, piperettine, asarinine, pellitorine, piperundecalidine, piperlongumine, piperlonguminine, refractomide $\mathrm{A}$, pregumidiene, brachystamide, brachystamide-A, brachystine, pipercide, piperderidine, longamide and tetrahydropiperine, terahydropiperlongumine, dehydropipernonalinepiperidine, piperine, terahydropiperlongumine and trimethoxy cinnamoyl-piperidine and piperlongumine have been found in the root of $P$. longum (Zaveri et al., 2010). Piperidine is used as a marker compound in P. longum (Saraf and Saraf, 2013). Different plant parts of $P$. longum revealed the presence of various important bioactive compounds viz. alkaloid, flavonoids, glycosides, tannin, phenol and sterol (Rami et al., 2013). A large number of compounds now referred to as piperine-type alkaloids or alkamides or piperamides have been isolated commonly from species belonging to the genus piper (piperaceae). Family Piperaceae species specialize in the production of amides, phenylpropanoids, lignans and neolignans, benzoic acids and chromenes, alkaloids, polyketides, and a plethora of compounds of mixed biosynthetic origin (Kato and Furlan, 2007). Among the different extraction method of piperine that was confirmed by qualitative analysis and TLC in Piper longum. The purity of the compound can be ascertained by UV, FTIR studies and by differential scanning calorimetry (DSC). (Swapnaet al., 2012). A method was developed for the isolation of piperine from the fruit of Piprenigum ( Kanakiet al., 2008). A simple, rapid, accurate and specific HPTLC method developed and validated and proposed to used for the routine analysis of P.longum fruit material and its formulations (Hamrapurkar et al., 2011).The RPHPLC method to standardize the various parts of $P$. Guineense used in isolation of piperine was characterized by carrying out NMR, UV and mass spectroscopy analyses (Adosraku et al., 2013). Establishment of libraries by HPLC chromatograms, where such sample tracing can be compared with reference as fingerprints in the evaluation of authentication and standardization methods has also been developed (Menghaniet al., 2010).

North East India is one of the plant biodiversity hotspots ( $50 \%$ of total India biodiversity) that harbours many rare and endemic Medicinal plants. P. longum is rarely cultivated in North Eastern region. It is still extensively collected from the wild, threatening the very existence of the plant (Nair, 2000). Survey of the literature indicates that not much attention has been paid to the spatio-temporal distribution of piperine in $P$. longum. In view of this, the present topic is of great concern to explore the piperine contentin different P.longum germplasms collected from selected location of North East region in order to find a prominent germplasm for safe and more holistic alternatives to the piperine extraction leading to synthetic drugs so often used now-a-days with the objective to determine the piperine content variation in different $P$. longum germplasms collected from different locations of North East India through RPHPLC method.

\section{MATERIALS AND METHODS}

General experimental procedures: The experimental field was ploughed 2-3 times and then laid in Randomized Block design with three replications in a net area of $120 \mathrm{sqm}$. The rooted cuttings of already collected ten numbers of $P$. longum germplasms from some selected areas of North East region were planted in pits@ two numbers per pit at spacing of $60 \mathrm{~cm} \mathrm{x}$ $60 \mathrm{~cm}$ (Plant to plant and row to row) having individual plot size of $2 \mathrm{~m} \times 2 \mathrm{~m}$ and eighteen numbers of plants was incorporated per plot. The present germplasms were collected from different North East region on the basis of availability of that location for further study under research (Table 1). Gap filling was done as per the need till one month after planting. The second crop was maintained by following recommended cultural practices including fertiliser application from the first crop due to the perennial nature of the crop.

The Bio-chemical analysis for piperine content of the selected ten Piper longum germplasms was conducted in the Bio-chemical laboratory of Bio-chemistry and Agricultural Chemistry, Assam Agricultural University (AAU), Jorhat for two successive years 2013-14 and 2014-15.

The per cent piperine content in fruit of the selected Piper longum germplasm was determined in High Performance Liquid Chromatography (HPLC)method (Hamrapurkar et al., 2011) by using the purity (\%) formula (Purity $(\%)=($ Amount of concentration found/ Amount of concentration taken)*100.HPLC grade solvent methanol was purchased from Merck, Mumbai, India. Deionized water used throughout the experiment obtained from a Millipore water purification system (Millipore, Mili-Q, France). Standard Piperine was procured from Sigma Aldrich, Bangalore, India.

Extraction and purification of piperine: Fruits of $P$. longum were dried in shade and ground into fine powder and was used for preparation of extract. Plant samples were extracted by refluxing at $100{ }^{\circ} \mathrm{C}$ with $4 \%$ water in methanol (sample:solvent ratio 1:20) on water bath for 3 hours (Adosraku et al., 2013). Extracts thus obtained were concentrated under reduced pressure (768-7mmhg). Concentrated extracts obtained were 
Table 1. List of collected germplasms for making rooted cutting.

\begin{tabular}{cll}
\hline SI No. & Germplasms & \multicolumn{1}{c}{ Collected location } \\
\hline 1 & PLJ-01 & Khetri, Assam \\
2 & PLJ-03 & Namgui, Arunachal Pradesh \\
3 & PLJ-09 & Umrangso, Meghalaya \\
4 & PLJ-11 & Sarupathar, Assam \\
5 & JPL-16 & Dharmanagar, Tripura \\
6 & PLJ-17 & East kameng, Arunachal Pradesh \\
7 & PLJ-19 & East kameng, Arunachal Pradesh \\
8 & PLJ-20 & Jagirod, Assam \\
9 & PLJ-30 & Boxirhat, Assam \\
10 & Check (Viswam) & Kerela \\
\hline
\end{tabular}

Table 2. Piperine content (\%) in extract and fruit among different germplasm of P. longum.

\begin{tabular}{|c|c|c|c|c|c|c|}
\hline \multirow[b]{2}{*}{ Germplasm } & \multicolumn{3}{|c|}{ Piperine in extract (\%) } & \multicolumn{3}{|c|}{ Piperine in fruit $(\%)$} \\
\hline & $1^{\text {st }}$ year & $2^{\text {nd }}$ year & Pooled mean & $1^{\text {st }}$ year & $2^{\text {nd }}$ year & Pooled mean \\
\hline $\begin{array}{l}\text { PLJ-01 } \\
\end{array}$ & 22.38 & 22.54 & 22.46 & 4.34 & 4.5 & 4.42 \\
\hline PLJ-03 & 22.86 & 23.02 & 22.94 & 5.38 & 5.54 & 5.46 \\
\hline PLJ-09 & 31.11 & 31.27 & 31.19 & 7.56 & 7.72 & 7.64 \\
\hline PLJ-11 & 26.51 & 26.67 & 26.59 & 7.77 & 7.93 & 7.85 \\
\hline JPL-16 & 5.61 & 5.77 & 5.69 & 1.25 & 1.41 & 1.33 \\
\hline PLJ-17 & 22.89 & 23.05 & 22.97 & 6.25 & 6.41 & 6.33 \\
\hline PLJ-19 & 39.83 & 39.99 & 39.91 & 5.16 & 5.32 & 5.24 \\
\hline PLJ-20 & 6.90 & 7.06 & 6.98 & 1.59 & 1.75 & 1.67 \\
\hline PLJ-30 & 42.28 & 42.44 & 42.36 & 6.44 & 6.60 & 6.52 \\
\hline Check (Viswam) & 21.43 & 21.59 & 21.51 & 5.07 & 5.23 & 5.15 \\
\hline S. Ed $( \pm)$ & & & 0.59 & & & 0.33 \\
\hline CD (5\%) & & & 1.21 & & & 0.68 \\
\hline
\end{tabular}

further vacuum dried $\left(70^{\circ} \mathrm{C}\right)$ to remove traces of residual solvent.

Preparation of standard: A $10 \mathrm{mg}$ amount of piperine standard was weighed accurately for preparation of standard stock solution and dissolved in $10 \mathrm{ml}$ methanol in a $50 \mathrm{ml}$ volumetric flask to get $1000 \mu \mathrm{g} / \mathrm{mL}$. From the standard solution, working solutions was prepared for required concentration of $40,50,60,70,80,90$, $100 \mu \mathrm{g} / \mathrm{mL}$ on serial dilutions method.

Preparation of samples: Stock solutions of different extracts were prepared by dissolving extract in methanol $(1000 \mu \mathrm{g} / \mathrm{mL})$ and filtered through a $0.45-\mu \mathrm{m}$ membrane filter. For stock solutions, $10 \mathrm{mg}$ of piperine sample was accurately weighed and quantitatively transferred into a $100 \mathrm{ml}$ volumetric flask. Approximately $50 \mathrm{ml}$ methanol was added and the solution was sonicated for $30 \mathrm{~min}$. The flask was filled upto $100 \mathrm{ml}$ with methanol then mixed and filter.
Stock solutions of the standards and extract samples were stored at $4^{\circ} \mathrm{C}$ and were brought to room temperature before use.

Chromatographic conditions and method validation: HPLC system for chromatographic analysis consisted of a separation module (Waters 600E) equipped with Empower software (Waters) and comprising of quaternary pump, an in-line vacuum degasser and a photodiode array detector (Waters 2996). The chromatographic separation was carried out in an isocratic elution mode on RP-18 column (Lichro Cart, Merck, Mumbai, India) with $5 \mu \mathrm{m}$ particle size, $4.6 \mathrm{~mm}$ internal diameter and $250 \mathrm{~mm}$ length. The mobile phase was a mixture of methanol and water $(80: 20)$. The solvent flow rate was $1.0 \mathrm{~mL} / \mathrm{min}$ and the injection volume was $20 \mu \mathrm{L}$. The photo diode array detector wavelength was set at $342 \mathrm{~nm}$ for the identification of piperine in all extracts. Chromatographic 
peak was identified on the basis of 5.6 minute retention time. Concentration of piperine in extract samples was calculated by comparing the integrated peak area of standard piperine with that of a standard curve prepared from standard piperine.

Calibration curve of piperine: Seven different concentrations of stock solution $(40,50,60,70,80,90$, $100 \mathrm{ppm}$ ) after dilution with methanol were injected in triplicates and regression equation and co-efficient of correlation (r2) was derived. Calibration curve for piperine $(5.0-100 \mu \mathrm{g} / \mathrm{mL})$ was prepared by injecting the different concentrations of standard samples, recording their peak areas and plotting peak areas obtained versus concentration.

Regression analysis was used to access the linearity of the developed HPLC method using the equation (1).

$\mathrm{y}=\mathrm{mx}+\mathrm{c}$ ....1

where, $\mathrm{x}$ corresponds to the concentration of standard solution $(\mu \mathrm{g} / \mathrm{ml}), y$ to the peak area and $\mathrm{m}$ is slope of the line and $\mathrm{c}$ is the intercept of the straight line with $\mathrm{y}$ axis.

Calibration curve was linear in this concentration range with regression coefficient $\left(\mathrm{r}^{2}\right) \quad 0.9946$ and showed good linear regression equation (2).

$\mathrm{y}=148532 \mathrm{x}-754677, \mathrm{r}^{2}=0.9946$ . .2

Statistical analysis: A Complete Randomized Block (CRD) design was considered for analysis of observed data. All data were expressed as the mean of three replications under laboratory condition. Values were analysed by following SPSS-16 computer based software at $5 \%$ probability level and were considered to be significantly different.

\section{RESULTS AND DISCUSSION}

This present investigation was an attempt to isolate piperinecontent (\%) in both extract and dried fruits of different $P$. longum germplasms available in North Eastern region. The pooled mean in the extract ranged in between 5.69 to 42.36 per cent and presented in table 2 and figure 1 to 7 . The analysed data indicated that higher per cent piperine in extract was in

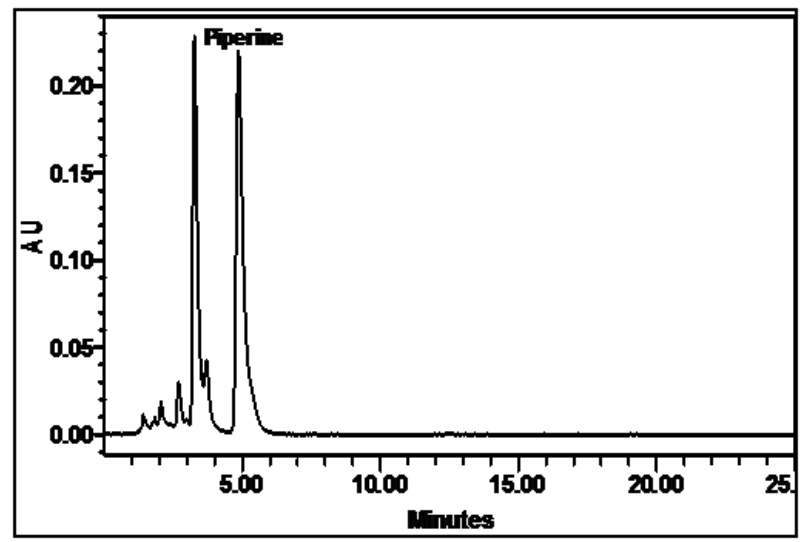

Fig. 1. HPLC chromatogram of PLJ-03. germplasm PLJ-30 (42.36) followed by germplasm PLJ-19 (39.91), PLJ-09(31.19), PLJ-17(22.97), which were significantly $(\mathrm{p}=0.05)$ superior over check variety (21.51). Determination of piperinein fruits revealed that piperine content varied from 1.33 to 7.85 per cent. The highest percent piperine content in fruits was observed in germplasm PLJ-11 (7.85) and differed significantly $(p=0.05)$ from germplasms PLJ-01, PLJ03, PLJ-16, PLJ-17, PLJ-19 and PLJ-20. The germplasm PLJ-09,PLJ-30,PLJ-17, PLJ-03 and PLJ-19 showed 7.64, 6.52, 6.33, 5.46 and 5.24 per cent piperine, respectively and was found to be betterthan check variety that recorded only 5.15 per cent of piperine content. Piperine content is $3-5 \%$ (on dry weight basis) in the fruits of Piper longum of commence (Madhaviet al., 2009). The percentage yield of $2.07 \% \mathrm{w} / \mathrm{w}$ of isolated piperine from Piper guineense compares favorably with the $2.50 \% \mathrm{w} / \mathrm{w}$ isolated from Piper longum (Deepthiet al., 2012). The difference in piperine content may be due to the methods of extraction and genetic character of the particular germplasm. The crude extract of $P$. longum contains $3-8 \%$ of piperine (James, 1999) that confirms the present findings. The highest per cent piperine content in JPL-11 may be for the particular genotype that has a potentiality of more piperine yield.

The highest percentage of piperine in extract than the piperine percentage in fruit was may be due to presence of some other compounds like isopiperolein $\mathrm{B}$, peperine, piperchabamide $\mathrm{D}$, dehydropipermolanine, N-isobutyl amide of octadeca-trans-2-cis-4dienoic acid and dehydropopermoline along with prepared extract. $P$. longum fruit extract confirmed the presence of chemical components including $\mathrm{N}$-isobutyl amide of octadeca-trans-2-cis-4-dienoic acid (Zaveri et al., 2010), piperidine (Saraf and Saraf, 2013), isopiperolein $\mathrm{B}$, peperine, piperchabamide $\mathrm{D}$, dehydropipermolanine and dehydropopermoline (Siddiqueet al., 1997), alkaloid piperine (1-piperoyl piperidine) and piper longamine (Storhet al., 2001) that confirms the present findings. The presence of various important

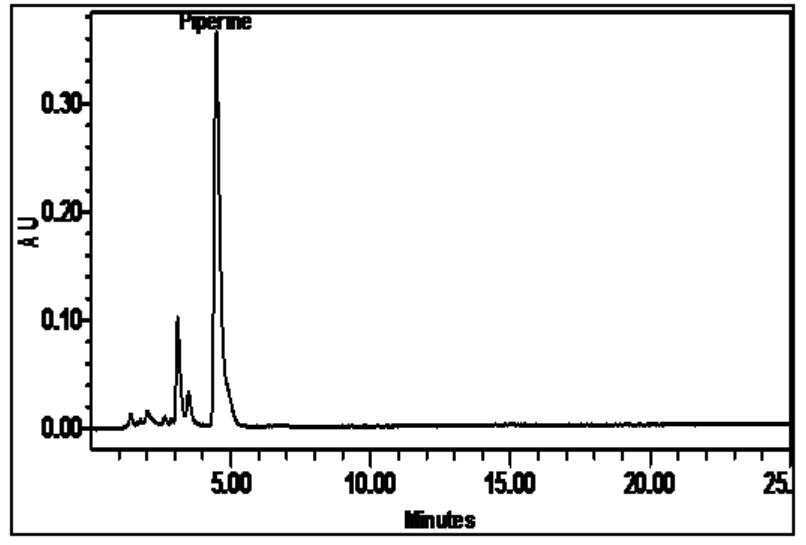

Fig. 2. HPLC chromatogram of PLJ-09. 


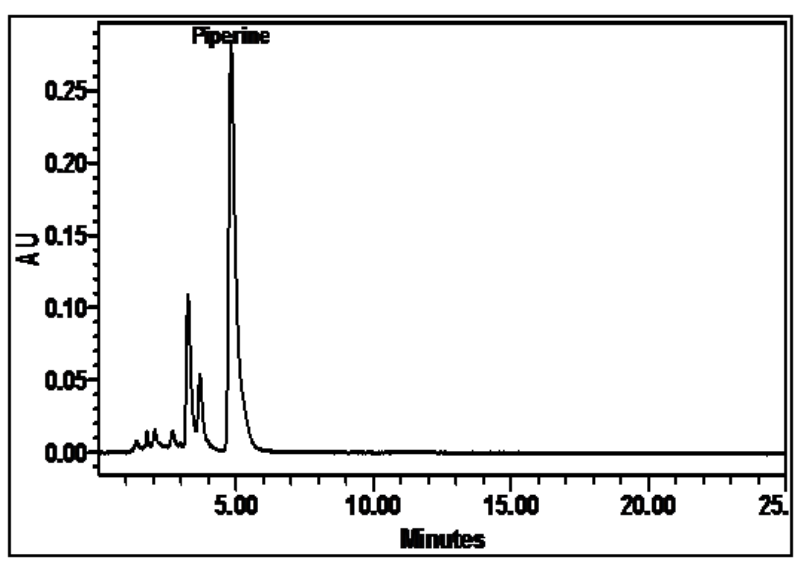

Fig. 3. HPLC chromatogram of PLJ-11

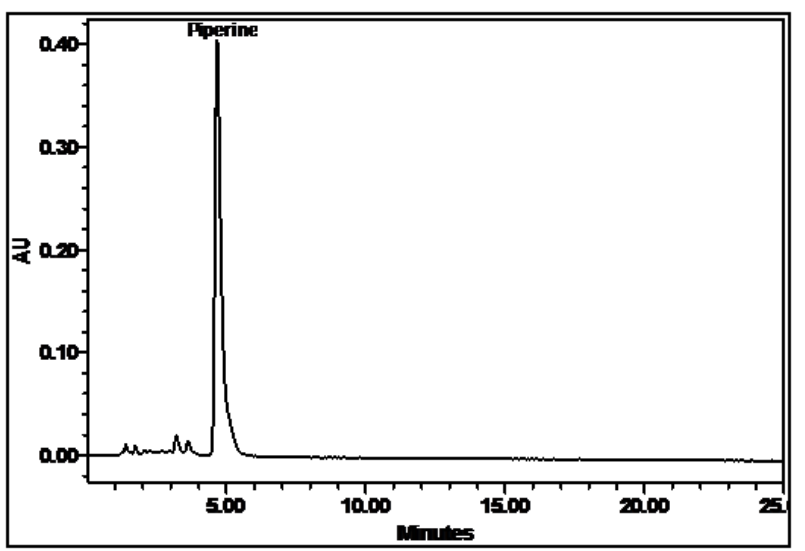

Fig. 5. HPLC chromatogram of PLJ-19.

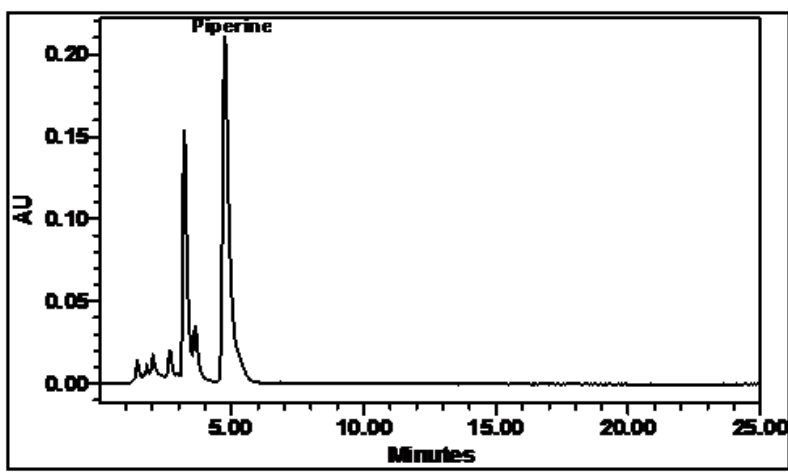

Fig. 7. HPLC chromatogram of check variety "Viswam".

$\mathbf{A U}=$ Absorbance Unit (milli absorption units mAU) (Fig. 1-7)

bioactive compounds viz. alkaloid, flavonoids, glycosides, tannin, phenol and sterol in plant parts of $P$. longum was also reported by Rami et al.(2013) in support of the present experimental result.

\section{Conclusion}

The present experimental findings revealed that the highest per cent piperine content in extract was found in germplasm PLJ-30. The highest per cent piperine content in fruit was recorded in PLJ-11followed by

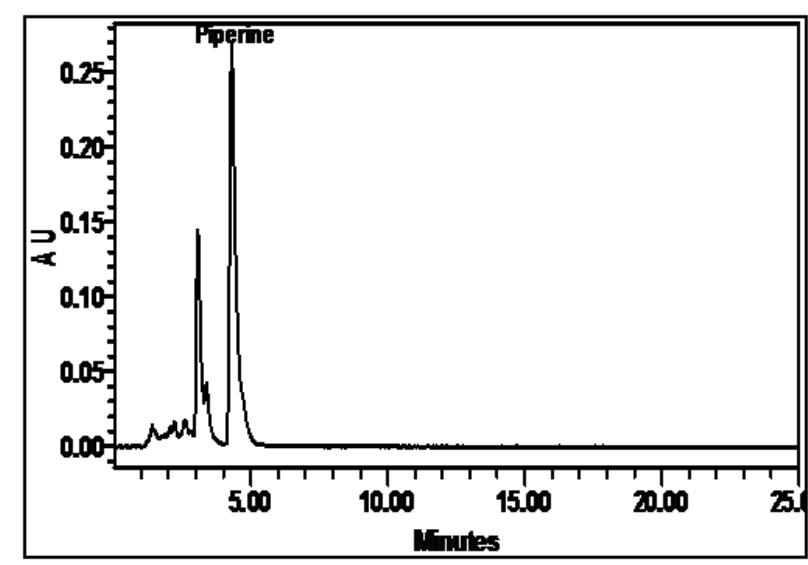

Fig. 4. HPLC chromatogram of PLJ-17.

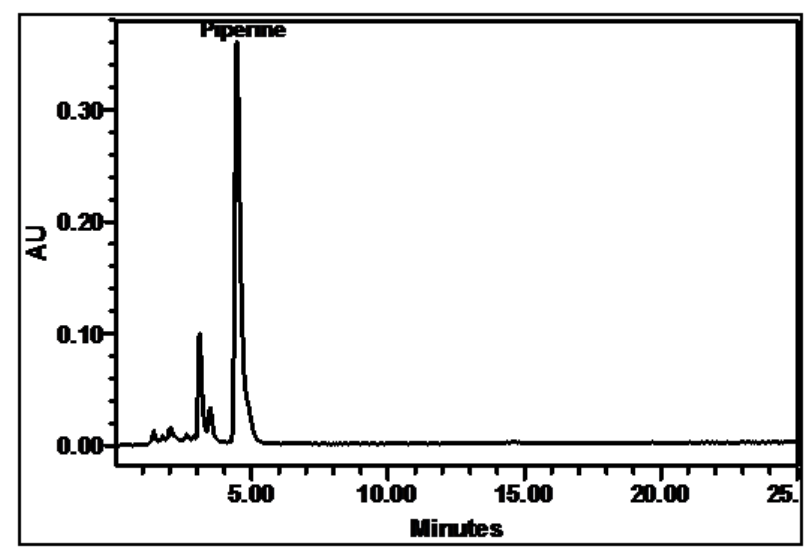

Fig. 6. HPLC chromatogram of PLJ-30.

germplasm PLJ-9 and significantly superior over check variety "Viswam" at 5\% probability level. It can be revealed from the present experiment that these two piper germplasmsthat yielded high piperine content has a great scope for commercial cultivation as alkaloid piperine has great demand in pharmaceutical useand may be the future source for preparation of modern drugs. Proper management and conservation of this promising and threatened $P$. longum germplasm along with large scale propagation for commercial cultivation at farmers field can be the cost effective future source of piperine.

\section{REFERENCES}

Adosrakul, R. K., Kyekyeku1, J. O. and Attah, I. Y. (2013). Characterization and HPLC quantification of piperine isolated from Piper guineense(Fam. Piperaceae).International Journal of Pharmacy and Pharmaceutical Sciences, 5(1):252-256

Atal, N. and Bedi, K.L. (2010). Bioenhancers: Revolutionary concept to market. J AyurInteg Med., 1(2): 96-99

Choudhury, P. R., Choudhury, M. D.,Ningthoujam, S. S., Das, D., Nath, D. and Talukdar, A. D (2012). Ethnomedicinal plants used by traditional healers of North Tripura district, Tripura, North East India. Journal of Ethnopharmacology, 166: 135-148 
Chauhan, K., Solanki, R., Patel, A., Macwan, C. and Patel, M. (2011).Phytochemical and Therapeutic potential of Piper longumLinn.A review.IJRAP, 2(1): 157-161

Deepthi, S.P.R.,Junise, V.,Shibin, P., Senthila, S. and Rajesh, R.S. (2012).Isolation, identification and antimycobacterial evaluation of piperine from Piper longum. Der Pharmacia Lettre, 4: 863-868

Hamrapurkar, P.D., Jadhav, K. and Zine, S. (2011). Quantitative estimation of piperine in Piper nigrumand Piper longumusing high performance thin layer chromatography, $J$ Applied Pharm Sci., 01 (03): 117-120

James, V. (1999).Piperine: the treasured alkaloid in Piper nigrum. Spice India, 12: 9-12

Kanaki, N., Dave, M., Path, H. and Rajani, M. (2008).A rapid method for isolation of piperine from the fruits of Piper nigrumLinn.JNAT, 62: 281-283

Kato, M.J. and Furlan, M. (2007). Chemistry and evolution of the Piperaceae, Pure Appl. Chem., 79(4): 529-538

Kumar, V., Shriram, V. and Mulla, J. (2013).Antibiotic resistance reversal of multiple drug resistant bacteria using Piper longumfruit extract.J App Pharma Sci., 3 (03):112-116

Manoj, P., Soniya, E. V., Banerjee, N. S. and Ravichandran, P. (2004). Recent studies on well known spice Piper longum Linn. Natural Product Radiance, 3(4): 22-29

Madhavi, B.B., Nath, A.R.,Banji, D., Madhu, M.N., Ramalingam, R. and Swetha D. (2009).Extraction, identification, formulation and evaluation of piperine in alginate beads.International Journal of Pharmacy and Pharmaceutical Sciences, 1: 156-161

Menghani, E., Jain, S.C. and Jain, R. (2010).Scientific validation of Piper nigrumby HPLC and anti-oxidative assay markers.Asian J Biotech, 2: 133-138

Mishra, P. (2010). Isolation, spectroscopic characterization and computational modeling of chemical constituents of Piper longumnatural product.Int J Pharm Sci Review Res., 2(2): 78-86

Nair, K.K.N. (2000). Manual of nonwood forest produce plants of Kerala. Kerala Forest Research Institute, Kera- la, $268-270$

Okwute, S.K. and Egharevba, H.O. (2013). Piperine-type amides: Review of the chemical and biological characteristics. Int $J$ Chem., 5(3) ISSN 1916-9698 E-ISSN 1916-9701

Rami, E., Sipai, S. and Patel, I. (2013). Studies on qualitative and quantitative phytochemical, analysis of Piper longumLinn, Int J Pharma Bio Sci., 4(3): (B) 1381 1388

Saraf, A. and Saraf, A. (2013).Chemical fingerprint profile and antibacterial studies on Piper longumLinn.Int. Conf. Exhib. Trad. Alter. Med.

Sharma, V.,Renuka, K.,Palak, V.,Harisha, C.R. and Prajapati, P.K. (2012).Pharmacognostical and phytochemical study of Piper longumL.andPiper retrofractum VAHL.

Siddique, B. S., Begum, S., Gulzar, T.and Farhat, N. F. (1997). An amide from fruits of Piper nigrum.Phytochemistry, 45: 1617-1619

Storh, R. J., Xiao, P. G. and Bauer, R.(2001). Constituents of Chinese Piper species and their inhibitory activity on prostaglandin and leukotriene biosynthesis in vitro.J of Ethnapharmacology, 75(2): 133-139

Sunila, E.S. and Kuttan, G. (2004) Immunomodulatory and antitumor activity of Piper longumLinn and piperine, 90 (2-3): 339-346

Swapna, P.R.D.,Junise, V.,Shibin, P., Senthila, S. and Rajesh, R.S. (2012).Isolation, identification and antimycobacterial evaluation of piperine from Piper longum. Der Pharmacia Lettre, 4(3): 863-868

Tapsell, L.C., Hemphill, I.,Cobiac, L., Patch, C.S., Sullivan, D.R.,Fenech, M.,Roodenrys, S., Keogh, J.B., Clifton, P.M., Williams, P.G., Fazio, V.A. and Inge, K.E. (2006). Health benefits of herbs and spices: the past, the present, the future. Med. J. Aust.,185(4): S4-24

Zaveri, M.,Khandhar, A., Patel, S. and Patel, A. (2010). Chemistry and pharmacology of Piper longumLin., 5 (1): $67-76$ 